\title{
A New Lycid Genus from the Dominican Amber (Insecta, Coleoptera, Lycidae, Leptolycinae, Leptolycini)
}

\author{
Sergey V. Kazantsev \\ Coleoptera Division, Insect Centre, 13-326 Donetskaya Street, Moscow 109651, Russia \\ Correspondence should be addressed to Sergey V. Kazantsev, kazantss@yahoo.com \\ Received 16 August 2011; Revised 22 September 2011; Accepted 22 September 2011 \\ Academic Editor: Bethia King
}

Copyright () 2012 Sergey V. Kazantsev. This is an open access article distributed under the Creative Commons Attribution License, which permits unrestricted use, distribution, and reproduction in any medium, provided the original work is properly cited.

A new fossil genus, Electropteron gen.n., and a new species, E. avus sp.n., are described from the Dominican Amber. Electropteron avus gen.n., sp.n., appears to be related to some of the extant Great Antillean lycids and is the first fossil taxon from the subfamily Leptolycinae.

\section{Introduction}

No taxa of the family Lycidae have so far been known from the ambers of the New World. All previously described amber lycids come from the Baltic Amber and all belong to the subfamily Erotinae [1-3], although Klebs [4] signaled, also from the Baltic Amber, a representative of Lygistopterus Mulsant, 1838 (Calochrominae).

The first Dominican Amber lycid, a well preserved and clearly observable male specimen, turned out to represent a new genus and a new species, apparently very close to some of the recent Leptolycinae from Hispaniola and Puerto Rico. Its gender is easily defined by the characteristic structure of the terminal abdominal segments, with the elongate, pointed at apex ultimate sternite enveloped laterally by a tergite. The description of the new taxon is given below.

\section{Description}

\subsection{Electropteron gen.n.}

\subsubsection{Type Species: Electropteron Avus sp.n.}

Description. Adult male. Alate, slender, elongate (Figure 1(a)). Head subquadrate, slightly narrowed behind eyes. Fastigium right-angled. Eyes relatively small, spherical. Maxillary palps slender, with ultimate palpomere pointed distally. Gula prominent. Antennal prominence conspicuous, antennal sockets approximate. Antenna 11-segmented, moderately long, slightly widening distally; antennomeres 411 flattened, with slightly uneven edges, antennomeres 2 and 3 short, transverse, subequal in length (Figure 2(a)); pubescence on antennomeres 4-11 relatively short and erect (Figures 1(a) and 1(b)).

Pronotum small, ca. 6 times shorter than elytra, transverse, trapezoidal, with obscure median impression in posterior third; posterior angles produced laterally (Figure 1(a)). Prosternum short, V-shaped (Figures 1(b), 2(b)). Thoracic spiracles small, not projecting beyond coxae. Mesoventrite transverse, short. Mesonotum with rather prominent, elongate scutellum (Figure 1(a)). Elytra long, narrowing, and dehiscent distally, covering abdomen, except genital capsule, with two noticeable primary costae (presumably, costae 2 and 4); interstices irregularly areolate; short and erect elytral pubescence uniform (Figure 1(a)). Metaventrite transverse, with acute posterior angles; discrimen complete, attaining to mesosternum.

Pro- and mesocoxae elongate; metacoxae approximate; angle between metacoxae ca. $90^{\circ}$. Legs slender; trochanters elongate, but considerably shorter than femurs, cylindrical, connected to femora distally; femurs and tibiae flattened, tibiae straight, widened distally; tarsomeres 1-4 narrow, without plantar pads; all claws simple. Ultimate sternite and tergite elongate, pointed at apex (Figures 1(a), 1(b), and 2(c)).

Female. Unknown. 


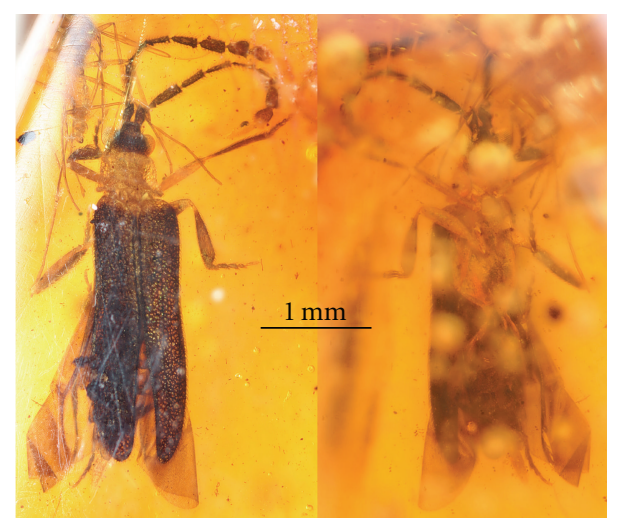

(a)

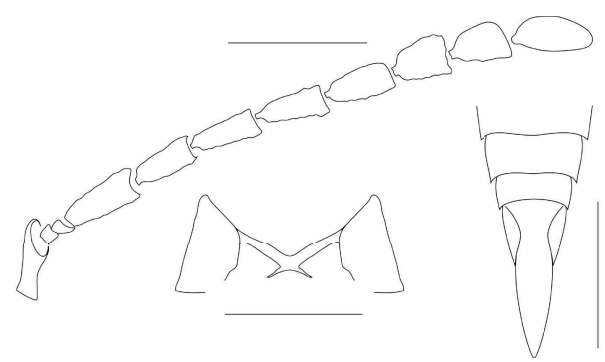

(a) (c)

FIGURE 2: Details of Electropteron avus gen.n., sp.n., holotype male: (a) antenna; (b) prosternum; (c) apex of abdomen, ventrally. Scale: $0.5 \mathrm{~mm}$.

margin, noticeable anterior, and small acute posterior angles. Scutellum parallel-sided and medially emarginate at apex (Figure 1(a)).

Elytra elongate, 3.3 times as long as wide at humeri, narrowing distally, dehiscent in distal two fifths, with two primary costae reaching their apices and costa 1 noticeable in proximal fourth (Figure 1(a)).

Legs are relatively short, tibiae subequal in length to femurs (Figures 1(a), 1(b)).

Length (from anterior head margin to end of abdomen): $3.3 \mathrm{~mm}$. Width (humerally): $0.7 \mathrm{~mm}$.

Female. Unknown. from Leptolycus Leng et Mutchler, 1922, another Greater Antillean extant endemic [5], by the flattened antennomeres 4-11, their short pubescence, transverse pronotum with explanate sides, and short V-shaped prosternum (Figures 1(a), 1(b), and 2(b)). On the other hand, Electropteron gen.n. is somewhat similar to Ceratoprion Gorham, 1884, distributed in the highlands of Central America and the Ands south to Ecuador, differing by the nonserrate antennomeres 4-11 and their erect pubescence and by the absence of the median longitudinal pronotal carina.

\subsection{Electropteron avus sp.n. Figures $1(a)-2(c)$}

2.2.1. Material. Holotype, Male, specimen no. 09155/ 2198988208, Dominican Amber, Oligocene (Insect Centre, Moscow).

Description. Male. Dark brown to black; antennomere 11, pronotum, scutellum, elytra proximally, at scutellar level, meso- and metaventrites, genital capsule, coxae, trochanters, and femurs yellowish.

Head with deep impression behind antennal prominence. Eyes small, interocular dorsal distance over 2 times greater than eye radius. Antennae attaining to elytral middle, with antennomere 3 subequal in length to pedicel (antennomere 2) and 5.5 times shorter than antennomere 4 (Figures $1(\mathrm{a})-2(\mathrm{a}))$.

Pronotum transverse, ca. 1.5 times as wide as long, slightly narrowing anteriorly, with almost straight anterior

Etymology. The name of the new species is derived from "avus," the Latin noun for "grandfather," alluding to its hypothetic ancestry to some of the extant Greater Antillean lycids.

Diagnosis. Electropteron avus sp.n., the only known representative of the genus, is easily distinguishable from the described extant lycids, as well as from the Baltic Amber lycid taxa, by the generic characters.

\section{Discussion}

Electropteron avus gen.n., sp.n., which is evidently close to some of the recent Leptolycini from Hispaniola and Puerto Rico, is tentatively attributed to the same tribe, although the tribe itself with the unusually wide range of morphologies of its members [5-7] may well prove to represent several independent lineages. The tribe Leptolycini is confined to Central America, Greater Antilles, and mostly northern part of South America. It is one of those enigmatic groups of netwinged beetles where females are not known and the pupa phase is presumably absent in female development [8]. The discovery of a representative of this group in the ca. 30million-year-old Dominican Amber, actually in the area of the current distribution of its close relatives, gives further clues for the reconstruction of the history and phylogenetics of the family. 


\section{Acknowledgments}

It is a pleasant duty to express gratitude to Mr. A. Allen (Boise, Idaho) for the possibility to study the remarkable Dominican Amber beetle specimen. Thanks are also due to Professor K. V. Makarov (Moscow) for his kind help with the color photos of Electropteron avus gen.n., sp.n.

\section{References}

[1] R. Kleine, "Eine Lycidae aus dem Baltischen Bernstein," Entomologische Blätter, vol. 36, no. 6, pp. 179-180, 1940.

[2] R. Kleine, "Nachtrag zu meiner Arbeit: "Eine Lycidae aus dem baltischen Bernstein"”, Entomologische Blätter, vol. 37, p. 47, 1941.

[3] J. R. Winkler, "Three new genera of fossil Lycidae from Baltic Amber," Mitteilungen der Münchner Entomologischen Gesellschaft, vol. 77, pp. 61-78, 1987.

[4] R. Klebs, "Über Bernstein einschlusse im allgemeinen und die Coleopteren meiner Bersteinsammlung," Schriften der Physikalisch-Okonomischen Gesellschaft zu Konigsberg, vol. 51, no. 3, pp. 217-242, 1910.

[5] S. V. Kazantsev, "Leptolycini of Puerto Rico (Coleoptera, Lycidae)," Russian Entomological Journal, vol. 18, no. 2, pp. 87-95, 2009.

[6] S. V. Kazantsev, "Neolyrium gen. n., first South American genus of net-winged beetles with 10-segmented antennae (Coleoptera: Lycidae)," Zootaxa, no. 1064, pp. 51-64, 2005.

[7] S. V. Kazantsev and A. A. Zaitsev, "Description of larval and imaginal stages of new species from the genera Pseudacroleptus Pic, 1911 and Ceratoprion Gorham, 1880 (Coleoptera: Lycidae: Leptolycinae)," Russian Entomological Journal, vol. 17, no. 3, pp. 283-242, 2009.

[8] S. V. Kazantsev, "Morphology of Lycidae with some considerations on evolution of the Coleoptera," Elytron, vol. 17-18, pp. 73-248, 2004. 

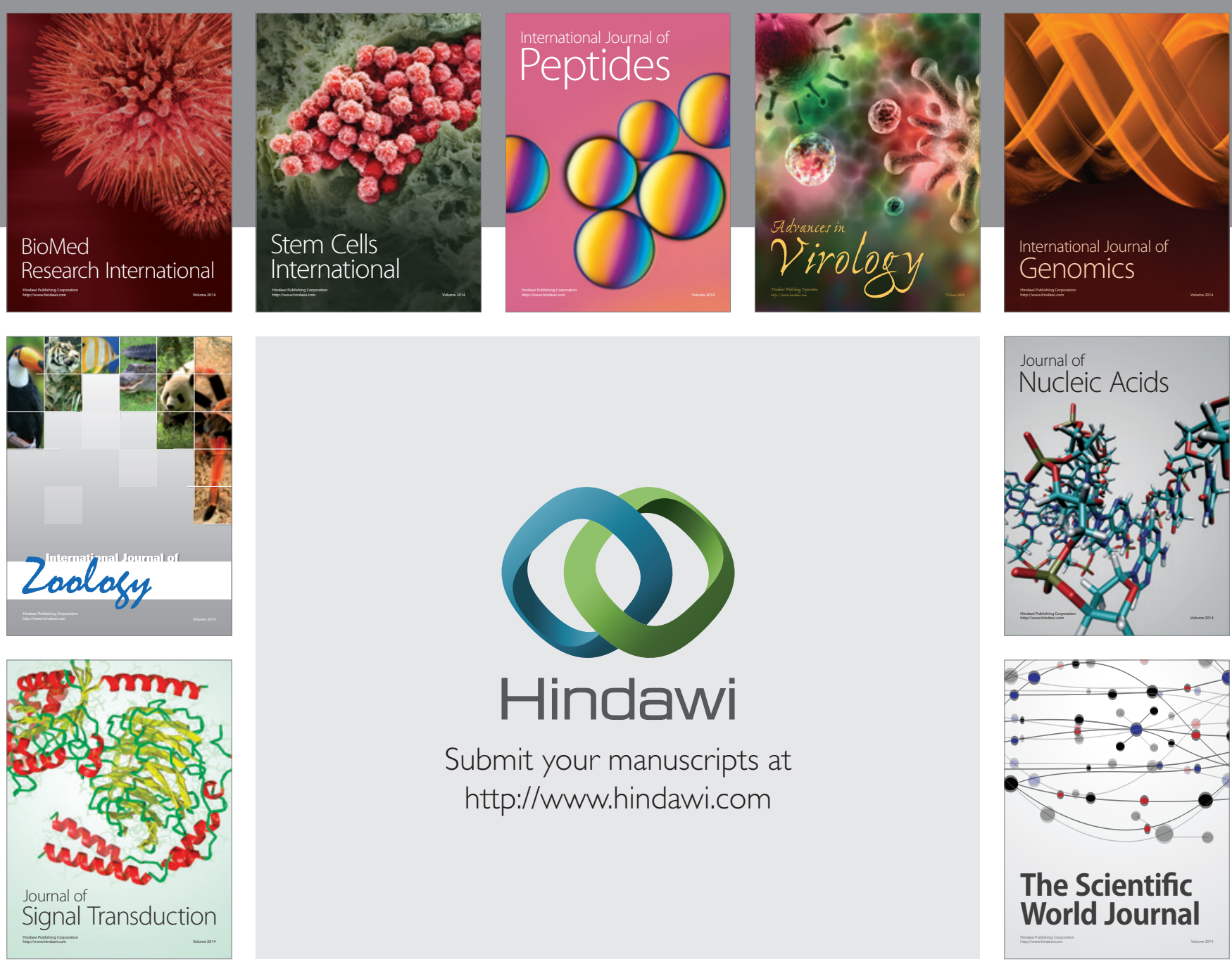

Submit your manuscripts at

http://www.hindawi.com
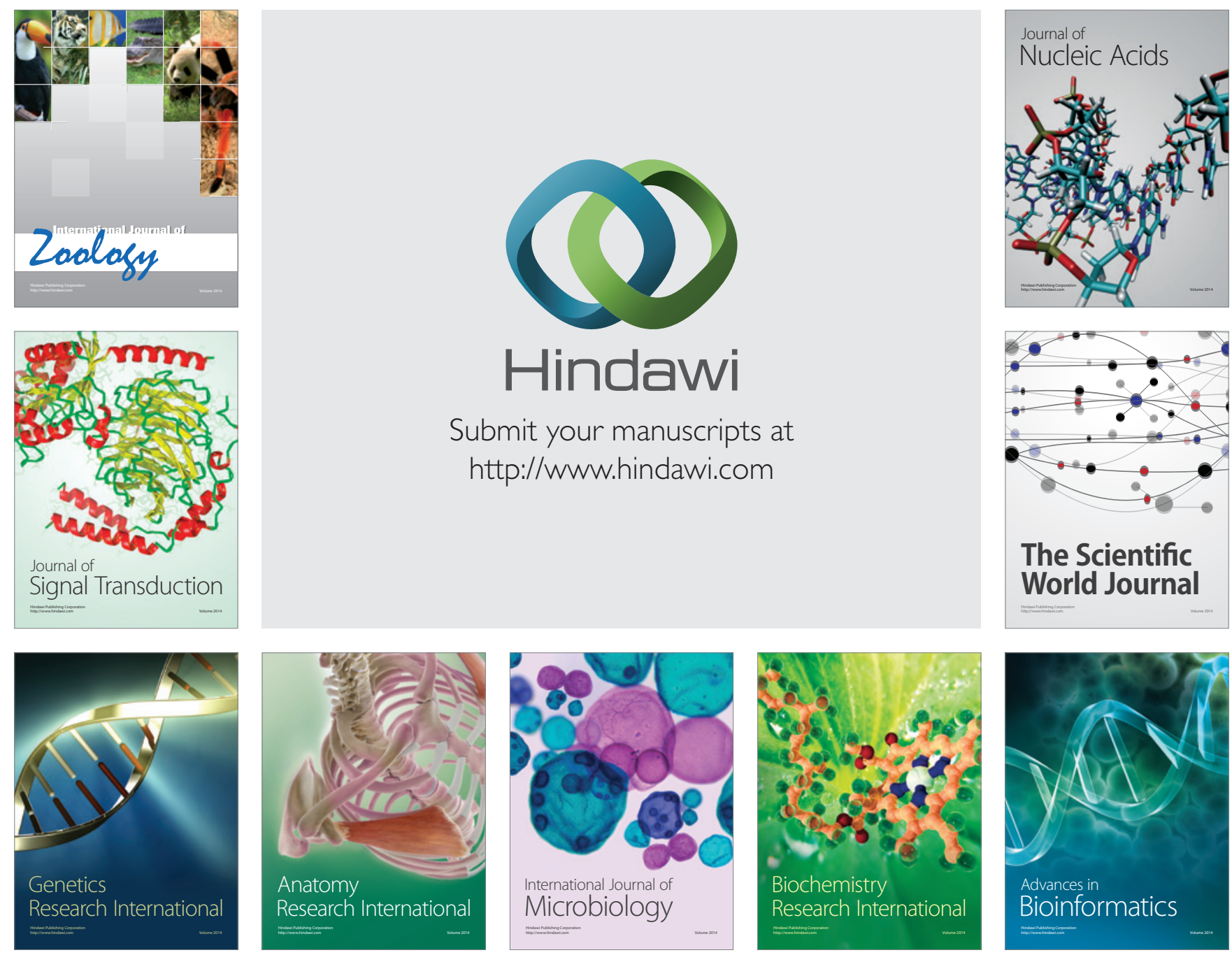

The Scientific World Journal
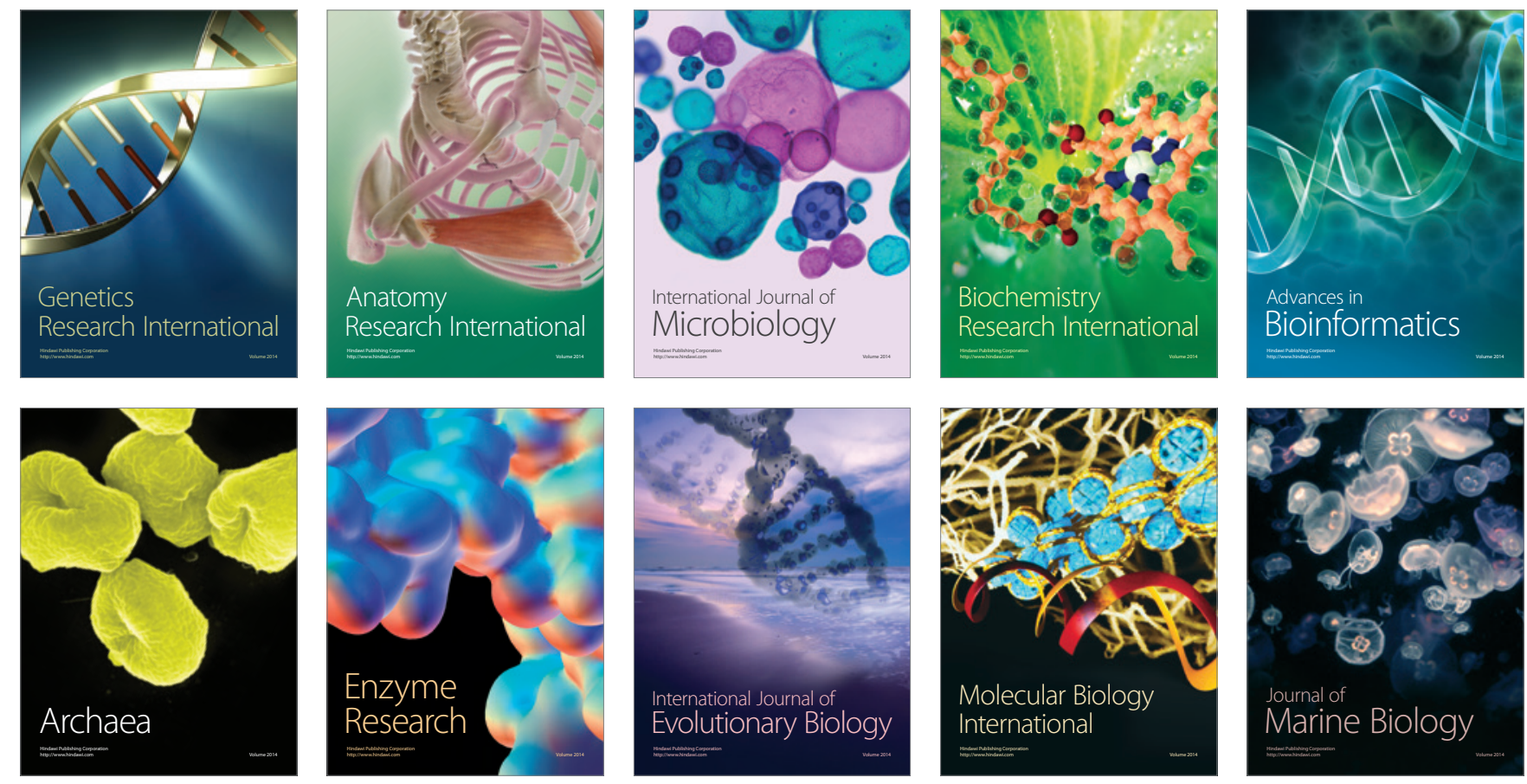